\title{
Network analysis of the variables involved in Career Development
}

\author{
Tatiane Cristine Froelich ${ }^{1}$ \\ Manoela Ziebell de Oliveira' \\ Wagner de Lara Machado ${ }^{1}$ \\ ${ }^{1}$ Pontifícia Universidade Católica do Rio Grande do Sul - PUCRS - Porto Alegre, Rio Grande do Sul, Brasil
}

\begin{abstract}
The aim of the study was to identify the relationships between career commitment and the perception of employability, career adaptability, self-reflection and insight of professionals from the southern region of Brazil. Participants were 535 individuals who answered an online questionnaire with sociodemographic questions and scales from career commitment, employability perception, career adaptability, self-reflection and insight, to evaluate the variables of interest in the study. The data were submitted to descriptive and network analysis. The results show a moderate and positive relationship between the variables studied and highlight the centrality and strength of the variables identity, planning and confidence among the analyzed variables. It is concluded that it is essential to encourage professionals to reflect on professional choices and their responsibility with their careers, based on the promotion of self-knowledge. Also, the role of organizations in the development of People Management practices that promote autonomy and relationships of trust stands out.

Keywords: professional development, vocational guidance, commitment, employability, graph theory
\end{abstract}

Análise de rede das variáveis envolvidas no Desenvolvimento de Carreira

\section{Resumo}

O objetivo do estudo foi identificar as relações entre comprometimento com a carreira e percepção de empregabilidade, adaptabilidade de carreira, autorreflexão e insight de profissionais da região Sul do Brasil. Participaram 535 indivíduos que responderam a um questionário on-line com questões sociodemográficas e escalas de comprometimento de carreira, percepção de empregabilidade, adaptabilidade de carreira, autorreflexão e insight, para avaliar as variáveis de interesse do estudo. Os dados foram submetidos a análises descritivas e de rede. Os resultados evidenciam relação moderada e positiva entre as variáveis pesquisadas e destacam a centralidade e força das variáveis Identidade, Planejamento e Confiança, entre as variáveis analisadas. Conclui-se que é fundamental estimular profissionais a refletir sobre escolhas profissionais e a sua responsabilidade com a carreira, a partir da promoção do autoconhecimento. Também, destaca-se o papel das organizações no desenvolvimento de práticas de Gestão de Pessoas que promovam autonomia e relações de confiança.

Palavras-chave: desenvolvimento profissional, orientação vocacional, comprometimento, empregabilidade, teoria dos grafos

\section{Análisis de red de las variables involucradas en el Desarrollo Profesional}

\section{Resumen}

El objetivo del estudio fue identificar las relaciones entre el compromiso profesional y la percepción de empleabilidad, la adaptabilidad profesional, la autorreflexión y el insight de profesionales de la región sur de Brasil. Participaron 535 individuos que respondieron un cuestionario online con preguntas sociodemográficas y escalas compromiso profesional; percepción de empleabilidad; adaptabilidad profesional; autorreflexión e insight, para evaluar las variables de interés del estudio. Los datos fueron sometidos a análisis descriptivos y de red. Los resultados evidencian una relación moderada y positiva entre las variables investigadas y destacan la centralidad y fuerza de las variables identidad, planificación y confianza, entre las variables analizadas. Se concluye que es fundamental incentivar a los profesionales a reflexionar sobre elecciones profesionales y su responsabilidad con la carrera, a partir de la promoción del autoconocimiento. Asimismo, se destaca el papel de las organizaciones en el desarrollo de prácticas de Gestión de Personas que promuevan autonomía y relaciones de confianza.

Palabras clave: desarrollo profesional, orientación vocacional, compromiso, empleabilidad, teoría de grafos

\section{Introduction}

The national context of social, economic and political changes, the increase of unemployment rates, inflation and the resulting feeling of social insecurity and instability result in changes in people's behavior in relation to the labor market. Data of the third quarter of 2018 indicate that unemployment reached $11.7 \%$ of the country's economically active population, representing
12.7 million Brazilians. Also, there was a 1.8\% increase in the number of informal jobs (IBGE, 2018). The Institute of Applied Economic Research's (Ipea) study published in December 2018 shows that about 44\% of Brazilians with age between 24 and 35 years old with a graduate degree occupy jobs that require education below graduate level. The current economic and political crisis in Brazil has generated changes in labor relations, such as the approval of the labor reform Law 
$\mathrm{n}^{\mathrm{o}} 13.467$ (2017), sanctioned on July 13, 2017, which came into effect in November of the same year.

With the job reductions and the consequent excess of qualified labor force available in the market, the traditional career model characterized by linear, vertical progression, with financial ascension and psychological contract of mutual loyalty between individual and organization ceased to be the dominant reality (Baruch, Szucs, \& Gunz, 2015). Career advancement started to be made by horizontal or zigzag movements (Baruch, 2015). The organizations themselves started to establish a new psychological contract with individuals, according to which the worker would assume an active posture in face of market demands and in relation to the construction of their career (Fugate, 2006; Fugate, Kinicki, \& Ashforth, 2004, Sullivan \& Baruch, 2009).

The number of professionals who are oriented towards the so-called contemporary careers, marked by frequent changes in their professional trajectory and greater autonomy in relation to the management of their own trajectory (Oliveira et al., 2010), has shown an increase over the years. This new context requires professionals to develop new characteristics and behaviors so they can assume the management of their careers (Ribeiro, 2016; Santos, 2017). Therefore, the focus is no longer on the external career or on the planning career carried out by the company, but on the internal career and the individual planning (Baruch, 2006; Santos, 2017), that are the characteristics of a professional committed to his career (Ribeiro, 2016).

The commitment to the career comprehends the workers attitudes that drive them to their professional development, that is, the directions given, through the worker's behavior, to achieve the work-related goals (Magalhães, 2015). Committed individuals remain in their careers due to emotions that generate strong identification with the profession and the feeling of having made the right choice (Kashefpakdel, Newton, \& Clark, 2018).

These professionals foster career commitment and reduce job insecurity (Praskova, Creed, \& Hood, 2015), favoring individual perceptions of value for the labor market and career satisfaction. Thus, it reinforces the idea that individuals design their careers as they make their decisions based mainly on personal satisfaction, developing their skills in order to adapt to the job market (Baruch, SzYcs, \& Gunz, 2015).

Identified as employability, the adaptation to the labor market is seen as a requirement both for organizations, which need to remain competitive, and for professionals, who seek a successful career and need to remain active and survive such changes (Kashefpakdel, Newton, \& Clark, 2018). As the work environment becomes more dynamic, as well as the perceived employability, the adaptability gains importance, being characterized as a set of psychosocial resources (Praskova, Creed, \& Hood, 2015; Rudolph et al., 2017). These psychosocial resources are related to the individual's attitudes and competences towards themselves and their context and are closely related to the possibilities of successfully managing career-related tasks and transitions (Rudolph et al., 2017).

In this context, in the face of career direction possibilities, the individual becomes a producer and also a product of realities and social interactions. In order to signify it, the individual needs to develop self-awareness, a reflective dimension that seems to feed the process and precede choices, making professionals somehow favorable to psychic and social balance (Leal, Souza \& Souza, 2018). Thus, self-reflection and insight would be involved in the process of evaluating, reflecting and regulating their own feelings, thoughts and behaviors (Leal, Souza \& Souza, 2018).

The present study is justified when we consider that adult professionals nowadays face transitions between jobs, organizations and occupations more often than ever before and understand that career development explains how individuals integrate their vocational self-concepts into their work roles (Savickas, 2005). The goal of this study was to explore the possible relationships between career commitment, perception of employability, career adaptability, self-reflection and insights of Brazilian workers.

The first hypothesis of this study is based on the following assumptions: 1) self-management is relevant to the development of employability (Santos 2017); 2) the individual's career identity is related to employability, which consists of a synergistic set of individual characteristics guided by the individual's career identity (Kashefpakdel, Newton, \& Clark, 2018); 3) employees increasingly engage in behaviors of change in order to align their jobs with their own preferences, passions and motivations (Ribeiro, 2016; Santos, 2017). Therefore, it is hypothesized that:

H.1 Career commitment will have a positive correlation with perception of employability.

The second hypothesis of this study was based on the following theoretical assumptions: 1) The Career Construction Theory (Savickas, 2005; 2013) emphasizes career adaptability as a manifestation of the individual's 
skills and willingness to direct and manage his life work. This life work, in general, has an impact on the quality of reemployment (Zikic \& Klehe, 2006) and on subjective success in the career dimension (Moreira e Silva, 2018); 2) Career decision is understood as the clarity and certainty that an individual has about his professional goals, that are translated into professional projects with defined goals and plans to achieve them (Teixeira, 2010). Thus, it is proposed that:

H2. Career adaptability is a predictor of career commitment.

The third hypothesis considers that: 1) in the context of professional development, the increase in self-awareness can facilitate the understanding of the one's stress and anxiety and positively influence learning and performance (Leal, Souza \& Souza, 2018); 2) self-reflection and "insight" act on resilience levels, although "insight" maximizes this relationship, favoring adaptability in unfavorable scenarios and optimism regarding the future (Cowden \& Meyer-Weitz, 2016); 3) programs for developing self-reflection and coping skills while the student still in college level courses can improve the performance of future professionals, considering that the stress resulting from the practice is reduced when self-reflection and "insight" is increased (Eng \& Pai, 2015; Pai, 2015). Thus, the third hypothesis is proposed:

H3. Self-reflection and insight are predictors of career commitment.

The fourth and last hypothesis was based on the following assumptions: 1) those individuals who have greater career adaptability tend to manifest greater employability (Boto, 2011; Fraga 2013); 2) employers look for professionals with transferable employability skills that allow them to thrive in any business environment (Kashefpakdel, Newton, \& Clark, 2018); 3) employability can be understood as a specific form of active adaptability at work, which allows workers to identify and accomplish their career opportunities, facilitating movement between jobs, inside and outside organizations (Fugate et al., 2004 ). Thus, the fourth hypothesis of this study is proposed:

H4. Career adaptability acts as a mediator of career commitment and perception of employability.

\section{Method}

\section{Participants}

The study sample consisted of 535 professionals living in the southern region of the country, with ages between 18 and 65 years $(\mathrm{M}=33.80 \%$; $\mathrm{SD}=0.38)$, both sexes, $41.50 \%$ men and $58.50 \%$ women. Out of them, only $37.80 \%$ had children, $56.40 \%$ were attending or had already completed graduate school and $41.10 \%$ worked in a management position. The inclusion criteria in the sample were that they have a work experience of at least two years and to live in the southern region of the country. Participants were selected for convenience, through emails and invitations on social networks. The sample size was defined by means of a sample calculation, which considered the total population of the southern region of the country estimated at 29.754 million individuals (IBGE, 2018), considering a margin of error of 0.05 and confidence level of $95 \%$.

\section{Materials}

The online questionnaire for data collection for this research was composed of five scales, in addition to a set of questions used to describe the participants profile. The analyzed variables and the instruments used for this study are described below:

a) Sociodemographic characteristics. It was used an instrument with questions about age, sex, city, relationship status, information about children, education, income and type of employment relationship. Through this questionnaire it was possible to identify the profile of the participant.

b) Career Commitment. To measure this variable we use the scale developed by Carson and Bedeian (1994) validated in Brazil by Magalhães (2013), which seeks to assess the levels of Identity (identification and personal meaning of work), Career Planning (self-assessment of development needs and the establishment of career goals), and Resilience (resistance to career break in the face of adversity), of its respondents. For this variable, four items were used to evaluate each of the three dimensions, composing the instrument with 12 items, punctuated with a five-point Likert scale. As examples of items to assess Identity, we have expressions such as "My line of work/career field has great personal meaning for me" and "I strongly identify with the line of work/career field that I have chosen". In relation to Planning, there are examples such as "I have a strategy to achieve my goals in this line of work/career field" and "I don't usually think about my personal development in this line/career field (inverted item)". 
Finally, Resilience is measured through sentences such as "The problems I encounter in this line of work/career field sometimes make me question whether the gains are paying off (inverted item)" and "The discomfort associated with my line of work/career field sometimes seems very big to me. (inverted item)". Satisfactory internal consistency indexes were presented (Cronbach's alpha) (alpha $=0.77$ for Identity, alpha $=0.75$ for Planning, and alpha $=0.72$ for Resilience).

c) Self-reflection and Insight. These constructs were evaluated by the Grant et al. (2002)'s Australian scale, adapted and validated for use in Brazil by DaSilveira, DeCastro and Gomes (2012). It consists of 20 items in the form of statements, which must be scored using a five-point Likert scale. Eight are related to the Insight dimension which refers to the ability to inspect and evaluate thoughts, feelings and behaviors, and 12 to the Self-reflection dimension which refers to the state of internal understanding that one has about his thoughts, feelings and behaviors. The items "It is important for me to evaluate the things I do" and "I often think about how I feel about things" are examples of Self-reflection. Insight is measured by the items like "I am usually aware of my thoughts" and "Thinking about my thoughts makes me even more confused". It has satisfactory internal consistency indexes (Cronbach's alpha) (alpha $=0.90$ for self-reflection, and alpha $=0.82$ for Insight).

d) Career Adaptability: To evaluate this variable we used the Career Adaptability scale developed by Savickas \& Porfeli (2012) and validated in Brazil by Audibert and Teixeira (2015). It consists of 24 items, which must be scored using a five-point Likert scale. The items cover issues related to the four dimensions of career adaptability: concern (items 1 to 6), control (items 7 to 12), curiosity (items 13 to 18), and confidence (items 19 to 24). The concern dimension is measured by items such as "Think about how my future will be" and "Plan how to achieve my goals". The items that exemplify control are the sentences "Taking responsibility for my actions" and "Believing in my ability to direct my own life". Curiosity is measured by items such as "Explore options before making a choice" and "Investigate deeply the questions / doubts I have". Finally, Confidence is measured through items such as "Solve problems" and "Learn new skills". Satisfactory internal consistency indexes were applied (Cronbach's alpha) (alpha $=0.88$ for concern, alpha $=0.83$ for control, alpha $=0.88$ for curiosity, and alpha $=0.89$ for confidence).

e) Self-perception of Employability: The scale developed by Peixoto, Janissek and Aguiar (2015) was used to evaluate this variable, consisting of ten items in the form of statements, which must be answered on a six-point Likert scale. Out of the items total, four of them are related to the maintenance of the current job, and six items assess the perception of success in acquiring a new job if the individual loses the current one. It measures Acquisition through items such as "If I leave this company, I would have no difficulty getting another job" and "My professional experience guarantees me an advantage when applying for a job”. For the measurement of Maintenance, items such as "I don't feel threatened by the chance of losing this job" and "My competence means that I don't have to worry about losing my job". Satisfactory internal consistency indexes were applied (Cronbach's alpha) (alpha $=0.75$ for Maintenance, and alpha $=0.73$ for Acquisition).

\section{Procedure}

The realization of this study followed strictly ethical research standards, according to Resolution 466/2012 of the National Health Council (CNS). The project was submitted to the Research Ethics Committee (Information Retrieved by the Journal) and approved under the CAAE registration number 82019318.4.0000.5336.

Data collection was performed using an online questionnaire, made available on the Qualtrics platform. The research was published in the period from May to September 2018 on the social networks LinkedIn and Facebook and on the WhatsApp and email lists of researchers' contacts. Participants who accessed the questionnaire were given a free and informed consent form (ICF), with the option of agreeing or not to participate in the study. Those who consented to participate in the study had access to the questionnaire. At the ICF, participants were assured the confidentiality of the data, that their participation was voluntary and 
that they could stop collaborating with the research at any time without any harm or loss to them. Participants answered the sociodemographic questionnaire and, following the career commitment, the perception of employability, the career adaptability, the self-reflection and insight scales. The questionnaire lasted an average of 22 minutes for its completion.

\section{Data analysis}

Demographic data were analyzed using the statistical software Statistical Package for Social Sciences (SPSS), version 21. The relationships between the variables of career commitment, career adaptability, perception of employability, self-reflection and insight were analyzed with the help of statistical software R. A descriptive statistical analysis was performed, calculating the mean and standard deviation of the variables. Subsequently, analysis of bivariate correlations and network analysis were performed (Borsboom \& Cramer, 2013) using the qgraph package (Epskamp, Cramer, Waldorp, Schmittmann, \& Borsboom, 2012) and these data were represented in graphs. Descriptive measures closeness and measure of expected influence were applied.

\section{Results}

\section{Descriptive analysis}

Regarding the general score of commitment to the career, the sample had an average of $3.64(\mathrm{SD}=0.73)$, which indicates that they are above the average point presented in the scale validation article $(\mathrm{M}=3.43)$, characterizing themselves as professionals committed to their career. Likewise, the dimensions of identity (M $=4.10, \mathrm{SD}=0.79)$ and planning $(\mathrm{M}=3.77, \mathrm{SD}=0.93)$ had high results while resilience $(\mathrm{M}=3.06, \mathrm{SD}=1.14)$ obtained a medium result.

Among the indices of perception of employability, self-reflection and insight, it was found that all dimensions, namely, acquisition $(\mathrm{M}=4.93, \mathrm{SD}=0.66)$, maintenance $(\mathrm{M}=3.95, \mathrm{SD}=1,26)$, self-reflection $(\mathrm{M}$ $=2.66, \mathrm{SD}=0.54)$ and insight $(\mathrm{M}=2.60, \mathrm{SD}=0.58)$, presented median results in relation to the average obtained in the scale validation study. Regarding career adaptability, all dimensions achieved median results: concern $(\mathrm{M}=3.51, \mathrm{SD}=0.86)$, control $(\mathrm{M}=3.94, \mathrm{SD}$ $=0.73)$, curiosity $(\mathrm{M}=3,65, \mathrm{SD}=0.82)$, confidence $(\mathrm{M}=4.08, \mathrm{SD}=0.68)$, but higher than the average obtained in the scale validation study. These results suggest that the workers participating in this study are committed to their careers, have a good perception of their employability, demonstrate self-reflection and insight, as well as adaptation to the challenges of their work context.

\section{Correlation analysis}

The correlation analysis respected the criteria established by Mukaka (2012), which defines the correlations of values (positive or negative) as moderate between 0.50 and 0.70 and low between 0.30 and 0.50 , respectively. The bivariate correlations showed moderate positive relationships between the dimensions of career commitment (identity, planning and resilience) and between the dimensions of career adaptability (concern, control, curiosity and confidence), and in relation to the acquisition dimension of the perception of employability. The relationship between the dimensions of commitment to the career and the variables self-reflection and insight and perception of employability (maintenance dimension) are considered low. The correlations also point to a moderate relationship between career adaptability and perception of employability and insight. Significant but low and negative correlation relationships between self-reflection and commitment to the career (resilience dimension) and perception of employability (maintenance dimension) were also found, as described in Table 1.

The partial correlations, also described in Table 1 , indicate that the dimensions of commitment to the career (identity and planning) have a low relation with the acquisition dimension and have no relation with the maintenance dimension, both dimensions of perception of employability. It also shows that the maintenance variable is only related to acquisition, both variables of perception of employability, and this relationship is of a moderate level. There is also a low but positive correlation between self-reflection and identity and a negative correlation with resilience, both variables of commitment to the career, while insight has a positive and low correlation with resilience. The concern dimension, of career adaptability, has only correlation with the planning dimension, of commitment to the career, and this relationship is positive and moderate. The relationship between the dimensions of career adaptability are low and moderate. Control correlates with insight, curiosity correlates with planning and confidence correlates with identity and acquisition, these are all positive and low correlations. Still, confidence has a low and negative correlation with planning, a dimension of commitment to the career. 
Table 1.

Bivariate and partial correlations between the variables of interest dimensions

\begin{tabular}{lccccccccccc}
\hline Dimensions & 1 & 2 & 3 & 4 & 5 & 6 & 7 & 8 & 9 & 10 & 11 \\
\hline 1.Identity & - & 0,31 & 0,16 & 0,12 & 0,00 & 0,15 & 0,00 & 0,00 & 0,00 & 0,00 & 0,17 \\
2.Planning & 0,49 & - & 0,14 & 0,13 & 0,00 & 0,00 & 0,00 & 0,34 & 0,00 & 0,08 & $-0,16$ \\
3.Resilience & 0,27 & 0,29 & - & 0,00 & 0,00 & $-0,17$ & 0,23 & 0,00 & 0,00 & 0,00 & 0,00 \\
4.Acquisition & 0,34 & 0,37 & 0,09 & - & 0,43 & 0,00 & 0,00 & 0,00 & 0,00 & 0,00 & 0,15 \\
5.Maintenance & 0,17 & 0,21 & 0,12 & 0,49 & - & 0,00 & 0,00 & 0,00 & 0,00 & 0,00 & 0,00 \\
6. Self- reflection & 0,21 & 0,22 & $-0,07$ & 0,09 & $-0,04$ & - & 0,00 & 0,00 & 0,00 & 0,00 & 0,00 \\
7.Insight & 0,24 & 0,27 & 0,31 & 0,22 & 0,20 & 0,07 & - & 0,00 & 0,12 & 0,00 & 0,00 \\
8.Concern & 0,35 & 0,57 & 0,22 & 0,39 & 0,26 & 0,21 & 0,28 & - & 0,11 & 0,33 & 0,14 \\
9.Control & 0,34 & 0,41 & 0,20 & 0,35 & 0,25 & 0,12 & 0,33 & 0,57 & - & 0,22 & 0,35 \\
10.Curiosity & 0,35 & 0,46 & 0,18 & 0,39 & 0,23 & 0,20 & 0,30 & 0,68 & 0,64 & - & 0,34 \\
11.Confidence & 0,37 & 0,31 & 0,13 & 0,40 & 0,21 & 0,08 & 0,27 & 0,55 & 0,65 & 0,67 & - \\
\hline
\end{tabular}

Note. bivariate correlations are on the lower diagonal while partial correlations are on the upper diagonal

\section{Network. Analysis}

The partial correlations, that is, the relationships after controlling the effects of the other variables and their respective investigated dimensions, described in Table 1, are represented graphically in Figure 1. In comparison with the bivariate correlations, it is noticed that the network maintains only those relationships more stable and less dependent on this system.

In Figure 2, we present the measures of closeness and strength for the partial correlations network of commitment to the career, perception of employability, career adaptability, self-reflection and insight in the evaluated sample. It is possible to observe that planning, confidence and identity are the dimensions with the closest proximity (closeness), having a smaller distance from the other variables, considering that they have the largest number of observed connections due to all possible ones. While confidence, curiosity and concern have a higher level of expected influence, that is, when shown they have a greater capacity to influence the state of the other dimensions.

\section{Discussion}

The main objective of this study was to understand the relationships between the variables of career commitment, career adaptability, perceived employability, self-reflection and insight. The results show that, in the first or second level, all variables were related in a weak or moderate way. The relationship between the variables perception of employability and career commitment (hypothesis 1), career adaptability and career commitment (hypothesis 2) and self-reflection and insight and the variable career commitment (hypothesis 3) is confirmed. Additionally, the results show that career adaptability does not measure the relationship between career commitment and perception of employability, refuting hypothesis four. The graph of the network analysis is generated by means of partial correlations. Partial correlations are conditional relations between two variables and their covariance with all other variables analyzed in the model. In a situation of variable $\mathrm{C}$ mediation on variables $A$ and $B$, it would be observable if, and only if, in the presentation of $C$ there was no partial correlation between A and B (Borsboom \& Cramer, 2013). In the graph, the relationships between the variables Identity and Planning (career commitment) with the variable Acquisition (employability) are clear. The variable Resilience (career commitment) has an indirect relationship with Acquisition, being mediated by the variables Identity and Planning. The only variable in the career adaptability group that has a direct relationship with employability was Confidence, and it relates to the variables Identity and Planning, which have a direct relationship with Acquisition, 


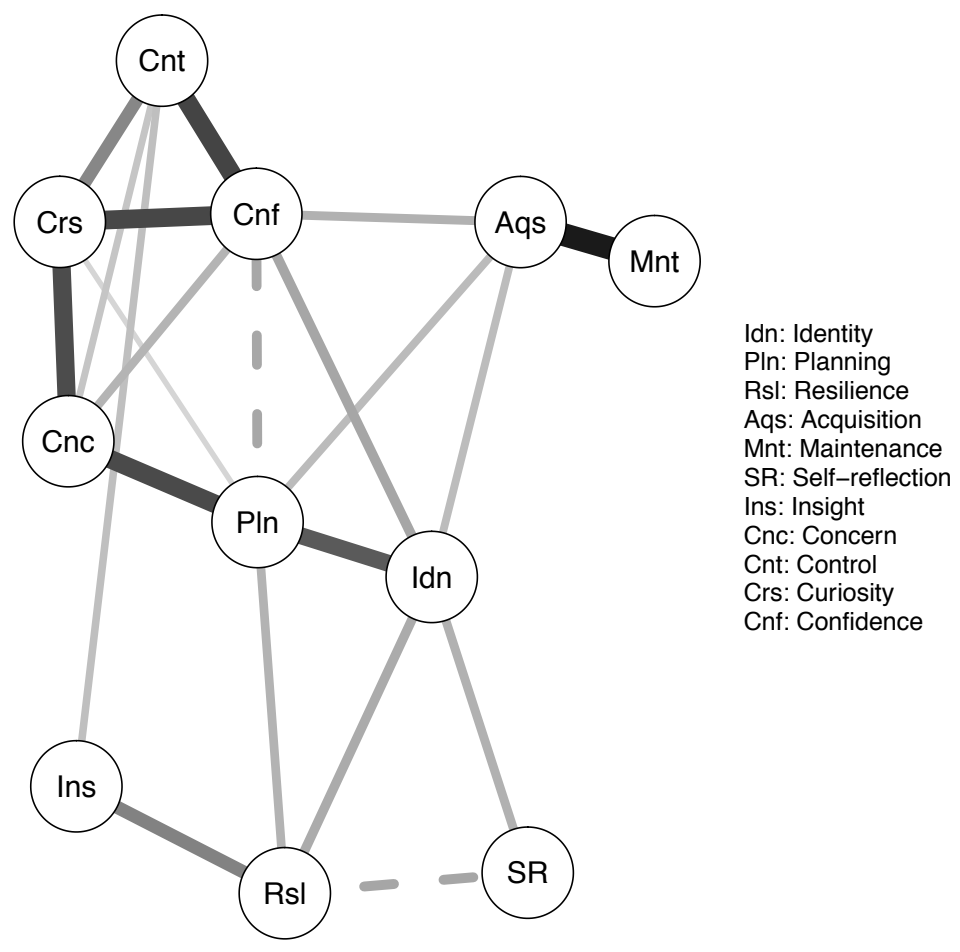

Figure 1. Glasso Method Network Analysis. Partial correlations between the dimensions of Career Commitment (Identity, Planning and Resilience), Perception of Employability (Acquisition and Maintenance), Self-reflection and Insight and Career Adaptability (Concern, Control, Curiosity and Confidence). Continuous lines: positive corrections; dotted lines: negative correlations.

thus indicating a non-mediating role of Confidence in these relationships.

When verifying the level of association between the dimensions of commitment to the career and perception of employability, foreseen in hypothesis 1 , it is evident that the maintenance dimension is only related to acquisition dimension, that are both dimensions of perceived employability, confirming findings of previous studies that affirm that being employable is more important than being employed (McArdle, Waters, Briscoe, \& Hall, 2007). The perception of employability is directly related to the dimensions of identity and planning, considered by Andrade, Fernandes and Bastos (2013) as the subjective aspect that best define commitment to the career. Based on the results found, it is assumed that the higher the level of identity, planning and resilience, the higher the professional's perception of employability. We consider that professionals committed to their career act as active agents that monitor and try to change their environments, and they take actions that meet their career goals (Vandenberghe \& Ok, 2013), seeking to align their jobs with their own preferences, passions and motivations (Ribeiro, 2016; Santos, 2017).

The importance of the planning and identity dimensions is reinforced when analyzing the results of the positive relationship of career adaptability and commitment to the career, as suggested in hypothesis 2. Corroborating previous studies, it is evident that professionals that are curious and concerned with their career investigate opportunities in order to expand and diversify the possibilities and perspectives of work (Fiori, Bollmann, \& Rossier, 2015). They seek to plan their career carefully to achieve their goals (Rudolph, Lavigne, Katz, \& Zacher, 2017).

It is also important to highlight the role of the confidence dimension in relation to career commitment, considering that career commitment is influenced by all the other dimensions of career adaptability and it is negatively related to planning and positively related to identity. Therefore, confident individuals, having a strong belief in the ability to overcome career barriers (Negru-Subtirica \& Pop, 2016), may end up planning their trajectory less, but seek to integrate their 

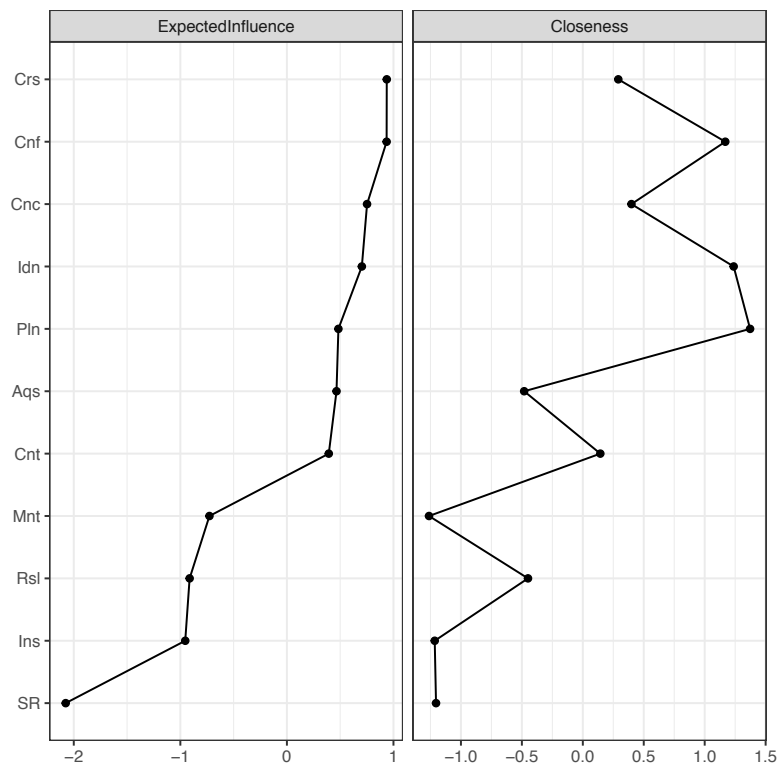

Figure 2. Subscale centrality measures

self-concepts in their work environments. They create coherent stories from career adaptability and then promote a strong sense of identity (Rudolph, Lavigne, Katz \& Zacher, 2017).

Similarly, individuals with high levels of career adaptability, especially in the confidence dimension, have a greater perception of employability. This strong positive relationship between confidence and employability is found in other studies (Attisgobe et al., 2016; Potgieter, Coetzee \& Ferreira, 2016; Gamboa, Paixão and Palma, 2015). This result also corroborates the study by Rudolph, Lavigne, Katz \& Zacher (2017) in which, considering the specificities of the research context, career adaptability explains $20 \%$ of the perception of employability and the confidence dimension explains $30.6 \%$ of it, showing to be a dominant factor in job performance. According to the authors, this relationship can be explained considering that career adaptability increases the development of skills that put the individual at a competitive advantage in relation to the desired job.

Employability is related to the proactive behavior of career management in constantly changing environments (Potgieter, Coetzee \& Ferreira, 2016). Thus, it is understood that people committed to the career and with a high level of career adaptability, especially confidence, believe they can solve problems, make choices and effectively pursue career goals. These people tend to be more adaptable to the dissatisfaction perceived in the career adaptability domain (Herachwati and Rachma, 2018; Kashefpakdel, Newton \& Clark, 2018).

For Fiori, Bollmann \& Rossier (2015), the way the individual perceives the work environment is related to the level of control, a dimension with a strong power of influence in the present model. Thus, the greater the level of control, the greater the individual's ability to adapt to the work context. The individuals own ability to change behavior, for Grant et al. (2002), is related to self-monitoring (self-reflection) and self-assessment (insight) skills. In order to deal more effectively with demands and emotion, or to adapt behaviors to overcome adversities, it is important that the individual develops an understanding of their thoughts and emotions, realizing that they have greater control over negative events and their emotions (Cowden \& MeyerWeitz, 2016).

The results of this study corroborate the findings of Cowden \& Meyer-Weitz (2016), when evidencing the association of self-reflection and insight with resilience. But it differs by indicating that the relationship between self-reflection and resilience is negative. In this case, the relationship is characterized by a process that can be dysfunctional, since reflecting on oneself, on one's own thoughts, feelings and behaviors may require a high conscious effort (Grant, 2001; Grant et al., 2002). In this context, the levels of self-reflection 
vary in the same direction as those of rumination (Silvia \& Phillips, 2011).

For Grant et al., (2002) an explanation for the divergent findings may be related to the different concepts of self-reflection that precedes ruminative processes and are devoid of emotional connections to reflect on thoughts, behaviors and emotions. For the author ruminative self-reflective results, such as anxiety, are subsequent to the self-reflection process. Considering that the correlation with the self-reflection dimension differs, Cowden \& Meyer-Weitz (2016) emphasize the importance of insight to sustain or improve psychological functioning.

Professionals with good cognitive flexibility are more likely to inhibit negative feelings and thoughts and to accept changes in the professional environment (Leal, Souza, \& Souza, 2018). Finally, the ability of people to overcome and face difficulties, frustrations and stresses common to work becomes fundamental in the current context. This ability is related to the ability to achieve a conclusive understanding (insight) about one's own thoughts, feelings and reasons in order to better evaluate them (Moreira, De Souza, \& Guerra, 2018).

The results of this study show that planning, confidence and identity, which were the variables with the highest number of connections in the analyzed network, are also the most sensitive dimensions. Therefore, any change made to the model will positively or negatively impact this set. The study also shows that the dimensions with the greatest interference power in the state of the other variables in this model are curiosity, confidence and concern. They also reinforce the importance of the professional perceiving himself as employable, increasing his confidence. And the importance of the professional using his curiosity and concern to investigate and diversify his possibilities of acting in a labor context marked by the reduction of formal work opportunities, as shown by the data from IBGE and Ipea. In addition to new work relationships, which consider contemporary careers and allow professionals committed to their careers to become responsible for their own trajectory (Oliveira et al., 2010).

Based on the results of this study, it is suggested to professionals who work with people's development the importance of stimulating the people's reflection on their planning and their identity, so they can become more committed to their career and less dependent on organization. In this way, it will be possible to assist them in their preparation for the future job market, and for changes that are already happening in some areas, so they develop a more adequate perception of their employability. We highlight the importance of assessing the level of confidence of the professional who is in the development process, considering that confidence and planning have a negative relationship, that is, professionals with a high level of confidence tend to plan less. And this characteristic is directly related to the individual's self-concept and level of self-knowledge, as well as the individual level of adaptability. For organizations, the importance of implementing People Management policies that promote relationships of confidence is reinforced, considering that these policies, if effectively practiced and perceived, will have a positive impact on the performance of employees.

Despite presenting promising and relevant results, the present study had limitations that should be mentioned. We recruited professionals from the southern region of Brazil through electronic dissemination which limited the sample size and profile. Still, the study did not relate the researched variables with sociodemographic data. For future research, the study suggests the importance of continuing to understand the relationship between career commitment, perceived employability, career adaptability, self-reflection and insight, also to seek to explore and relate these variables to sociodemographic dimensions such as age, sex, academic background. It is recommended to carry out longitudinal studies in contexts of personal and organizational development to show the impact of the variables highlighted in this study on the professional's performance.

\section{References}

Andrade, R. S., Fernandes, S. R. P., \& Bastos, A.V.B. (2013). Bem-estar subjetivo e comprometimento com a carreira: Examinando suas relações entre professores do ensino superior. Revista de Psicologia, 4(2), p. 47-60. Recuperado de: http:// periodicos.ufc.br/psicologiaufc/article/view/805

Attisgobe, K. A., Rossier, J., \& Paboussoum, P. (2016). Career adapt-abilities scale in Togo: Psychometric properties and relation to general self-efficacy, employability and entrepreneurial intentions. Manuscript in preparation.

Audibert, A., \& Teixeira, M. A. P. (2015). Escala de adaptabilidade de carreira: evidências de validade em universitários brasileiros. Revista Brasileira De Orientação Profissional, 16(1), 83-93 . Recuperado de: 
http://pepsic.bvsalud.org/scielo.php?script=sci_ar ttext\&pid=S1679-33902015000100009

Baruch, Y. (2006). Career development in organizations and beyond: Balancing traditional and contemporary viewpoints. Human resource management review, 16(2), 125-138 . doi: 10.1016/j. hrmr.2006.03.002

Baruch, Y., Szucs, N., \& Gunz, H. (2015). Career studies in search of theory: The rise and rise of concepts. Career Development International, 20(1), 3-20. doi: 10.1108/CDI-11-2013-0137

Borsboom, D., \& Cramer, A. O. J. (2013). Network analysis: An integrative approach to the structure of psychopathology. Annual Review of Clinical Psychology, 9, 91e121 . doi: 10.1146/ annurev-clinpsy-050212-185608

Boto, B. C. N. (2011). Relação entre adaptabilidade e empregabilidade: Um estudo exploratório com uma amostra do sector da construção civil (Dissertação de mestrado da faculdade de Psicologia de Lisboa). Recuperado de: http://hdl.handle. net/10451/4963

Carson, K. D. \& Bedeian, A. G. (1994). Career commitment: Construction of a measure and examination of its psychometric properties. Journal of Vocational Behavior, 44,237262 . doi: 10.1006/ jvbe.1994.1017

Cowden, R. G. \& Meyer-Weitz, A. (2016). Self-reflection and self-insight predict resilience and stress in competitive tennis. Social Behavior and Personality, 44(7), 1133-1150 . doi: 10.2224/ sbp.2016.44.7.1133

DaSilveira, A. C., DeCastro, T. G., \& Gomes, W. B. (2012). Escala de Autorreflexão e Insight: Nova Medida de Autoconsciência Adaptada e Validada para Adultos Brasileiros. Psico, 43(2), 155-162 - Recuperado de: http://revistaseletronicas. pucrs.br/ojs/index.php/revistapsico/article/ view/11693/8039

Eng, C.-J. \& Pai, H.-C. (2015). Determinants of nursing competence of nursing students in Taiwan: The role of self-reflection and insight. Nurse Education Today, 35(3), 450-455. doi: 10.1016/j. nedt.2014.11.021

Epskamp, S., Cramer, A. O. J., Waldorp, L. J., Schmittmann, V. D., \& Borsboom, D. (2012). qgraph:
Network visualization of relationships in psychometric data. Journal of Statistical Software, 48(4), 1e18 . doi: 10.18637/jss.v048.i04

Fiori, M., Bollmann, G., \& Rossier, J. (2015). Exploring the path through which career adaptability increases job satisfaction and lowers job stress: The role of affect. Journal of Vocational Behavior, 91, 113121 . doi: $10.1016 /$ j.jvb.2015.08.010

Fraga, S. I. D. (2013). Adaptabilidade e empregabilidade numa perspectiva construtivista: Estudo com desempregados em contexto de formação (Tese de Doutorado, Universidade de Lisboa). Recuperado de: https://repositorio.ul.pt/ bitstream/10451/7701/1/ulsd064596_td_Sandra_Fraga.pdf

Fugate M. (2006). Employability. In J. Greenhaus, \& G. Callanan (Eds.), Encyclopedia of career development (Vol. 1, pp. 267-271). Thousand Oaks, CA: SAGE.

Fugate, M., Kinicki, A. J., \& Ashfhort, B. E. (2004). Employability: A psycho-social construct, its dimensions, and applications. Journal of Vocational Behavior, 65, 14-38. doi: 10.1016/j.jvb.2003.10.005

Gamboa, V., Paixão, O., \& Palma, A. (2015). Adaptabilidade de carreira e autoeficácia na transição para o trabalho: O papel da Empregabilidade Percebida - Estudo com Estudantes do Ensino Superior. Revista Portuguesa De Pedagogia, 133-156. doi: 10.14195/1647-8614_48-2_7

Grant, A. M. (2001). Rethinking psychological mindedness: Metacognition, self-reflection, and insight. Behaviour Change, 8(18), 8-17. doi: 10.1375/ bech.18.1.8

Grant, A.M., Franklin, J. \& Langford, P. (2002). The Self-Reflection and Insight Scale: A new measure of private self-consciousness. Social Behavior and Personality, 30, 821-836. doi: 10.2224/ sbp.2002.30.8.821

Herachwati, N., Rachma, A. (2018), Organizational Commitment Versus Career Commitment. KnE Social Sciences, 371-38 3. doi: 10.18502/kss. v3i10.3388

Instituto Brasileiro de Geografia e Estatística - IBGE (2018). Censo Demográfico 2018 por estado: Trabalho - Amostra. Recuperado de: http://www. ibge.gov.br/estadosat/ 
Instituto Brasileiro de Geografia e Estatística - IBGE (2018). Pesquisa Nacional por Amostra de Domicílios Contínua Terceiro trimestre de 2018. Recuperado de: https://cidades.ibge.gov.br/ brasil/pr/panorama

Kashefpakdel, E., Newton, O. \& Clark, J. (2018). Joint Dialogue: How are Schools Developing Real Employability Skills?. Education and Employers, Edge Foundation and the National Education Union.

Leal, C. K. N., Souza, M. D. P., Souza, M. L. (2018). Autorreflexão e insight como dimensões da autoconsciência privada: Uma revisão da literatura. Psico, 49(3), 231-241. doi: 10.15448/1980-8623.2018.3.26732

Brasil (2017). Lei no 13.467, de 13 de Julho de 2017 (2017). Dispõe sobre as alterações nas Leis do Trabalho (CLT), aprovada pelo Decreto-Lei no 5.452, de 1 o de maio de 1943. Brasília - DF. Recuperado de http:/ /www.planalto.gov.br/ccivil_03/_ato20152018/2017/lei/L13467.htm

Magalhães, M. O. (2013). Propriedades psicométricas da versão brasileira da escala de comprometimento com a carreira. Psicologia: Ciência e Profissão [online], 33(2), 303-317. doi: 10.1590/S1414-98932013000200005.

Magalhães, M.O. (2015). Medidas do vínculo do trabalhador com a carreira. In K. Puente-Palacios, \& A. L. Peixoto (Eds.) Ferramentas de diagnóstico para organizações e trabalho: um olhar a partir da psicologia (pp. 302-314). Porto Alegre, RS: Artmed.

McArdle, S., Waters, L., Briscoe, J. P., \& Hall, D. T. (2007). Employability during unemployment: Adaptability, career identity and human and social capital. Journal of Vocational Behavior, 71, 247264 . doi: 10.1016/j.jvb.2007.06.003

Moreira, L. V., DeSouza, M.L. \& Guerra, V. M. (2018). Self-perception, empathy and moral self-concept predict moral concerns in adults. Paidéia, 28, e2818. doi: 10.1590/1982-4327e2818

Mukaka M. M. (2012). Statistics corner: A guide to appropriate use of correlation coefficient in medical research. Malawi medical journal: The journal of Medical Association of Malawi, 24(3), 69-71.

Negru-Subtirica, O., \& Pop, E. I. (2016). Longitudinal links between career adaptability and academic achievement in adolescence. Journal of
Vocational Behavior, 93, 163-170 . doi: 10.1016/j. jvb.2016.02.006

Oliveira, M. Z., Zanon, C., Silva, I. S. da, Pinhatti, M. M., Gomes, W. B., \& Gauer, G. (2010). Avaliação do autogerenciamento e do direcionamento de carreira: Estrutura fatorial da Escala de Atitudes de Carreira Proteana. Gerais: Revista Interinstitucional de Psicologia, 2(2), 160-169. Recuperado de http://www.fafich.ufmg.br/gerais/index.php/ gerais/article/view/99/57

Pai, H.-C. (2015). The Effect of a Self-reflection and Insight program on the nursing competence of nursing students: A longitudinal study. Journal of Professional Nursing, 31(5), 424-431. doi: 10.1016/j.profnurs.2015.03.003

Peixoto, A. D. L. A., Janissek, J., \& Aguiar, C. V. N. (2015). Autopercepção de Empregabilidade In K. Puente-Palacios, \& A. D. L. A. Peixoto (Eds), Ferramentas de Diagnóstico para Organizações e Trabalho: Um Olhar a partir da Psicologia (pp. 175-186). Porto Alegre, RS: Artmed.

Potgieter, I. L.; Coetzee, M; Ferreira, N. (2016). Employability capacities and organisational commitment foci of human resource professionals: An exploratory study, Journal of Psychology in Africa, 26(5), 436-442 Recuperado de http:// uir.unisa.ac.za/bitstream/handle/10500/23525/ Potgieter_Employability\%20capacities. pdf? sequence $=1$ \&is Allowed $=y$

Praskova, A., Creed, P. A., \& Hood, M. (2015). Self-regulatory processes mediating between career calling and perceived employability and life satisfaction in emerging adults. Journal of Career Development, 42(2), 86-101. doi: 10.1177/0894845314541517

Ribeiro, G. B. (2016). O comprometimento com a carreira e a percepção de sucesso na carreira: Estudos de caso com coaches que atuam na cidade de Belo Horizonte (Dissertação de Mestrado, Fundação Mineira de Educação e Cultura). Recuperado de: http://webcache.googleusercontent. com/search?q=cache:AyZXebY8_7EJ:www. fumec.br/revistas/pdma/article/download/4759/ $2820+\& \mathrm{~cd}=1 \& \mathrm{hl}=\mathrm{pt}-\mathrm{BR} \& \mathrm{ct}=\mathrm{clnk} \& \mathrm{gl}=\mathrm{br}$

Rizzatti, D. B. Sacramento, A. M., Valmorbida, V. S., Mayer, V. P., \& Oliveira, M. Z . (2018). Transição de carreira em adultos brasileiros: Um levantamento da literatura científica. Gerais: Revista 
Interinstitucional de Psicologia, 11(1), 153-173. doi: 10.36298/gerais2019110112

Robinaugh, D. J., Millner, A. J., \& McNally, R. J. (2016). Identifying highly influential nodes in the complicated grief network. Journal of Abnormal Psychology, 125(6), 747-757. doi: 10.1037/ abn0000181

Rudolph, C. W., Lavigne, K. N., \& Zacher, H. (2017). Career adaptability: A meta-analysis of relationships with measures of adaptivity, adapting responses, and adaptation results. Journal of Vocational Behavior, 98, 17-34. doi: 10.1016/j.jvb.2016.09.002

Rudolph, C. W., Lavigne, K. N., Katz, I. M., \& Zacher, H. (2017). Linking dimensions of career adaptability to adaptation results: A meta-analysis. Journal of Vocational Behavior, 102, 151-173. doi: 10.1016/j. jvb.2017.06.003

Santos, J. I. V. (2017). O papel do comprometimento profissional na relação de mediação entre gestão de carreira e o comprometimento organizacional. (Dissertação de Mestrado, Universidade de Lisboa). Recuperado de: https://www.repository.utl.pt/bitstream/10400.5/15025/1/ disserta $\% \mathrm{C} 3 \% \mathrm{~A} 7 \% \mathrm{C} 3 \% \mathrm{~A} 3$ o.pdf

Savickas, M.L. (2005). The theory and practice of career construction. In S. D. Brown \& R. W. Lent (Eds.), Career development and counseling: Putting theory and research to work (pp. 42-70). Hoboken, NJ: Wiley.

Savickas, M.L. (2013). Career construction theory and practice. In R. W. Lent \& S. D. Brown (Eds.), Career development and counseling: putting theory and reaserch to work (pp. 147-183). Hoboken, New Jersey: John Wiley \& Sons.

Savickas, M. L., \& Porfeli, E. J. (2012). Career AdaptAbilities Scale: Construction, reliability, and measurement equivalence across 13 countries. Journal of Vocational Behavior, 80(3), 661-673 doi: 10.1016/j.jvb.2012.01.011

Silvia, P. J. \& Phillips, A. G. (2011). Evaluating selfreflection and insight as self-conscious traits. Personality and Individual Differences, 50(2), 234237. doi: 10.1016/j.paid.2010.09.035

Sullivan, S. E., \& Baruch, Y. (2009). Advances in Career Theory and Research: A Critical Review and Agenda for Future Exploration. Journal of Management, 35(6), 1542-1571. doi: 10.1177/0149206309350082

Teixeira, M. A. P (2010, setembro). Desenvolvimento de carreira em universitários: Construção de um instrumento. In Anais do III Congresso Brasileiro de Psicologia Ciência e Profissão, São Paulo, SP.

Vandenberghe, C.; Ok, A. B. (2013). Career commitment, proactive personality, and work outcomes: A crosslagged study", Career Development International, 18 (7), 652-672 . doi: 10.1108/ CDI-02-2013-0013

Zikic, J., \& Klehe, U. C. (2006). Job loss as a blessing in disguise: The role of career exploration and career planning in predicting reemployment quality. Journal of Vocational Behavior, 69, 391409. doi: 10.1016/j.jvb.2006.05.007

Recebido em: 02/05/2019

Reformulado em: 14/04/2020

Aprovado em: 21/05/2020 
About the authors:

Tatiane Cristine Froelich is a psychologist graduated from the Lutheran University of Brazil (ULBRA) and she has a master's degree in Psychology from the Graduate Program in Psychology of the Pontifical Catholic University of Rio Grande do Sul. She is currently an associate researcher and a member of the Career Development Studies Group. She works as a teacher and is the founder and Consultant of Careers and People Management at Tatiane Froelich Consultoria.

ORCID: https://orcid.org/0000-0002-2615-6607

E-mail: tatianefroelichpsicologia@gmail.com

Manoela Ziebell de Oliveira is a psychologist, she completed her master and her PhD degree in Psychology at the Federal University of Rio Grande do Sul (UFRGS). She is currently an Adjunct Professor in the Stricto Sensu Graduate Program in Psychology of the Pontifical Catholic University of Rio Grande do Sul (PUCRS). Professor Oliveira coordinates the Career Development Study Group in the Graduate Program in Psychology at PUCRS.

ORCID: https://orcid.org/0000-0003-0243-5115

E-mail: manoela.ziebell@gmail.com

Wagner de Lara Machado is a psychologist graduated from the Lutheran University of Brazil (ULBRA), he has completed his master and his PhD in Psychology at the Federal University of Rio Grande do Sul (UFRGS). He is currently an Adjunct Professor in the Stricto Sensu Graduate Program in Psychology of the Pontifical Catholic University of Rio Grande do Sul (PUCRS). Professor Machado coordinates the Welfare and Mental Health Assessment Research Group.

ORCID: https://orcid.org/0000-0001-5555-5116

E-mail:wag.lm.psico@gmail.com

Contact:

Tatiane Cristine Froelich

Career Development Study Group (GEDC), Graduate Program in Psychology, Room 938

Pontifical Catholic University of Rio Grande do Sul

Porto Alegre-RS, Brazil

CEP: 90619-900

Phone / Fax +55 51 3320-7747 